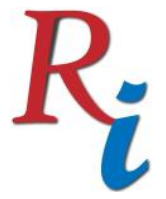

Asia Proceedings of Social Sciences

(APSS)

www.readersinsight.net/APSS

\title{
PRE-SERVICE TEACHERS’ REFLECTIVE PRACTICES: A \\ MALAYSIAN PERSPECTIVE
}

\section{S. Chee Choy}

Research Centre for Educational Psychology and Instructional Strategies Tunku Abdul Rahman University College, Perak Branch Campus Malaysia

choysc@mail.tarc.eu.my

\section{Joanne Sau Ching Yim}

Research Centre for Educational Psychology and Instructional Strategies Tunku Abdul Rahman University College, Perak Branch Campus Malaysia

yimsc@mail.tarc.edu.my

\section{Daljeet Singh Sedhu*}

Research Centre for Educational Psychology and Instructional Strategies Tunku Abdul Rahman University College, Perak Branch Campus Malaysia

daljeetsingh@tarc.edu.my

*Corrosponding author's Email: daljeetsingh@tarc.edu.my 


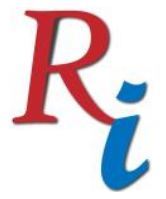

\section{Asia Proceedings of Social Sciences \\ (APSS) \\ www.readersinsight.net/APSS}

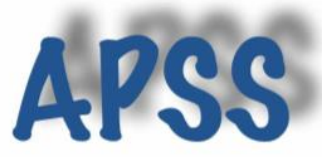

\section{A b s tract}

This study aimed to explore the use of reflective thinking practices incorporated into classroom teaching by pre-service teachers (PSTs). Firstly, this study investigated the reflective thinking practices used by PSTs to analyse their teaching strategies and approaches in the classroom. Secondly, this study explored the ways PSTs use reflective thinking to analyse their teaching practice. The qualitative method employing semi-structured interviews was used in this study. A sample of 11 female final year PSTs enrolled in Bachelor of Education programmes in a Malaysian university, who had just completed their 16-week teaching practicum was selected as the participants of this study. The data were analysed using the interpretive approach in order to allow the PSTs to voice their reflective thinking experiences. Analysis of the data yielded seven categories: Opportunities to reflect, Expression of feelings, Teaching awareness, Lifelong learning, Self-confidence, Self-assessment, and Self-belief. Overall, the findings of this study indicated positive perceptions by the PSTs about using reflective practices to help them teach

\section{Rese a r ch H igh I ight s}

The findings also showed that the reflection carried out by the PSTs favoured the technical and practical levels rather than being able to critically analyse their own teaching process.

The results also indicated that the PSTs were not open to negative feedback given by students, as they were looking more towards the popularity factor and acceptance from students than learning from the experience as a whole.

A major implication of the present study was that Malaysian PSTs may not know how to effectively use reflective thinking to help them improve their teaching skills at the same time cultivate critical thinking Highlight 2

\section{Research Objectives}

In the Malaysian Educaton Blueprint it was stated that a 2011 research study found that only 50 per cent of the lessons in schools are being delivered effectively where students are sufficiently engaged and actively participated in their lessons. Further to this, much of the 


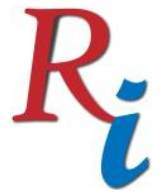

\section{Asia Proceedings of Social Sciences \\ (APSS) \\ www.readersinsight.net/APSS}

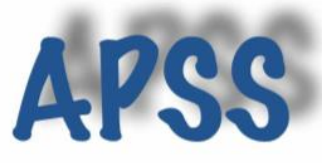

lessons in Malaysian classrooms focussed on surface-level content understanding instead of deep thinking skills. The same report also stated that this practice among teachers is a challenge for Malaysia as 60 per cent of its current teachers will still be teaching for the next 20 years. In view of these challenges, there is a definite need for effective skills to stimulate thinking in classrooms, as well as determine the use of and the effectiveness of reflective thinking skills incorporated during teacher training in bringing about the interpretation of skills needed to enhance future interactions within the classroom. Hence two research questions underpin this study:

1. What are the reflective thinking practices used by PSTs to analyse their teaching strategies and approaches in the classroom.

2. How do PSTs use reflective thinking to analyse their teaching practice

\section{Methodology}

\section{Data collection}

Final year PSTs enrolled in Bachelor of Education programmes who had just completed their 16-week practicum teaching in a Malaysian university were invited to participate in the study. A final sample of 11 female PSTs was selected to be interviewed based on recommendations from their lecturers that they were able to express and converse well in English.

\section{Profile of Sample}

The 11 PSTs that participated in the interviews were enrolled in the Bachelor of Education programmes in the Teaching English as a Second Language programme. These PSTs were all female in their fourth year of studies and were aged between 22 and 23 years.

\section{Analysis}

The data were analysed using the interpretive approach because this study is about giving voice to PSTs' reflective thinking experiences (Larkin, Watts \&Clifton, 2006). The intention is not to oversimplify the voices of individuals by summarising their opinions but rather to develop them at an interpretive level. 


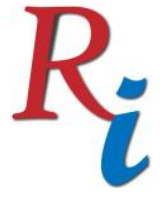

\section{Asia Proceedings of Social Sciences \\ (APSS) \\ www.readersinsight.net/APSS}

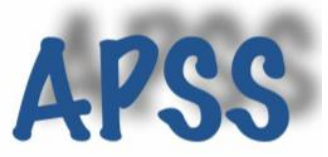

\section{Results}

On the whole the results showed that PSTs were positive about using reflective practices to help them with their teaching. However, the results also indicate that the reflection carried out by the PSTs were more on the technical and practical levels rather than critically analysing their teaching processes (Yaacob et al, 2014). The technical level focuses on the teacher and the success and failure of the techniques used, the practical level focuses on students' learning experiences and examination of strategies used and the critical level is where the teacher begins to question how the environmental context influences the way students learn. They were on the whole more concerned about how they were teaching than what their students were learning similar to findings by Nair and Ghanaguru (2017). As far as opportunities to carry out reflective thinking, most of the respondents were positive about this because they had to write their reflective journals as part of the course requirements.

\section{Findings}

The results of this study seem to indicate that Malaysian PSTs may not know how to use reflective thinking to help them improve their teaching skills. They are more involved with ensuring that they are evaluated well by their mentors than what their students are learning during their lessons. Their perspective is more on gaining recognition from their mentors that they are carrying out their duties well as teachers than reflecting on their teaching to selfimprove.

\section{Acknowledgement}

This research work is supported by Tunku Abdul Rahman University College Internal Grant UC/1/G2019-00039

\section{References}

Larkin, M., Watts, S., \& Clifton, E. (2006). Giving voice and making sense in interpretive phenomenological analysis. Qualitative research in Psychology, 3, 102-120.

Nair, P., \& Ghanaguru, S. (2017). Owning the classroom: Student teachers' experiences and concerns during practicum. The English Teacher, 46(3), 142-159. 


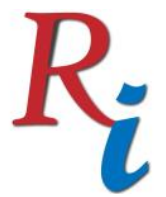

\section{Asia Proceedings of Social Sciences}

(APSS)

www.readersinsight.net/APSS

Yaacob, A., Walters, L. M., Ali, R. M., Abdullah, S. S., \& Walters, T. (2014). Reflecting on Malaysian teacher trainee's journal. Malaysian Journal of Learning and Instruction, 11, $1-21$.

Author's Biography

Associate Professor S. Chee Choy holds a PhD in educational psychology. Her research areas include perceptions and attitudes toward issues pertinent in teacher education and higher education.

Joanne Sau Ching Yim holds a PhD in social science and does educational research at the primary, secondary, and higher education levels. Her research areas include teachers' perceptions and attitudes towards educational policies and educational technology.

Daljeet Singh Sedhu holds a PhD in education. His research areas include teaching and learning strategies in higher education, teachers' and students' perceptions, applied linguistics, and second language acqusition among ESL learners. 